Research, part of a Special Feature on The Privilege to Fish

\title{
A Cautionary Note on Individual Transferable Quotas
}

\author{
$\underline{\text { U. Rashid Sumaila }}^{1}$
}

\begin{abstract}
Individual transferable quotas (ITQs) are a type of catch share system, which is a tool used by some governments to manage fisheries. Technical reasons for taking a rather cautious approach to the implementation of ITQs have been provided previously. In the current contribution, I first highlight the strengths and weaknesses of ITQs and then provide suggestions on how to design and implement these quotas to mitigate their weaknesses. ITQs need to be designed carefully as part of a broad ecosystem-based management scheme to meet the three generally accepted objectives of modern fisheries management: ecological, economic, and social sustainability.
\end{abstract}

Key Words: catch shares; ecological sustainability; economic sustainability; economic efficiency; exclusive and transferable rights; ecosystem-based fisheries management; fisheries; individual transferable quotas; ITQs; social sustainability

\section{INTRODUCTION}

Individual transferable quotas (ITQs) are a version of what are now popularly called "catch shares", a regulatory tool that some governments use to control fishing (Essington [2010] provides a recent assessment of catch shares). ITQs in particular have been the subject of much discussion recently (Grafton et al. 2007, Costello et al. 2008). This is a good thing because many of the world's fisheries are currently badly managed, and injecting more economic thinking into their management will almost surely bring improvements (for example, removing capacity-enhancing subsidies [Sumaila et al. 2008]). Such improvements will reduce economic waste in the world's fisheries, which is estimated to be up to $\$ 50$ billion a year (World Bank 2009). At the same time, it is important that the limits to ITQs be well acknowledged and taken into account during their implementation. Clark et al. (2010) provided technical arguments why there are limits to ITQ use in the management of fisheries. In this contribution, I will highlight the strengths and weaknesses of ITQs and provide suggestions for mitigating these weaknesses when designing and implementing such schemes.

ITQs are designed to give their owners exclusive and transferable rights to a given portion of the total allowable catch (TAC) of fish. Authorities establish a TAC for a given species and then divide this total among the individual fishers or firms in the form of individual catch quotas, usually as a percentage of the TAC. These ITQs are transferable through selling and buying in an open market. In theory, ITQs are de facto property (access rights or privileges). If effective, ITQs will remove the drive to "race for the fish"; they will instead create an incentive among fishers to regard the fishery resources as assets that promise to deliver a stream of economic benefits over the long term (Moloney and Pearse 1979, Squires et al. 1998). Hence, the tendency of fishers to overexploit the resource should be lessened (Munro and Pitcher 1996).

An ITQ is primarily an instrument for promoting economic efficiency, rather than conservation or equity (Hannesson 1996). Many studies of ITQ systems in operation around the world show that economic efficiency does indeed improve with the implementation of ITQ schemes (Arnason 1997, Grafton 1996, Dewees 1998). Hence, if economic efficiency were the only concern of fisheries management, then ITQs would be a great tool for achieving management objectives. However, from policy statements made by governments around the world and from the ongoing debate in the literature, it is clear that for fisheries managers, scientists, and 
the public, fisheries management is not about economic efficiency alone. It is also about conserving the resources, preserving the ecosystems that support the resources through time, and ensuring equity and social justice in the use of these resources.

\section{ECOLOGICAL CONCERNS WITH ITQ MANAGEMENT}

ITQ systems do not create full property rights in a fishery (Copes 1986, Bromley 2009). A full property right provides its holders with (i) complete security, (ii) full exclusivity, (iii) permanence, and (iv) unrestrained transferability. However, these four benefits are not all being conferred onto ITQ owners. For example, new ITQs currently being implemented in the USA have sunset clauses, so they are not permanent. The inability to assign full property rights to marine fish resources is due to their inherent nature as common property and part of a larger ecosystem. Because full property rights are not conferred, dishonest actions such as highgrading, discarding, quota busting, and misreporting will bring benefits to the individual fisher in the short term, while the long-term costs of such actions will be spread over all participants.

Even if ITQs did provide full property rights, it is possible under certain conditions to "empty" the ocean of a given fish species and use the proceeds to invest in other sectors of the economy. Such emptying would occur if the objective of ITQ owners was solely to maximize the discounted economic rent from the fishery and if the discount rate and the intrinsic growth rate of the fish were at suitable levels (Clark 1973, Sumaila and Bawumia 2000, Sumaila and Walters 2005, Prager and Shertzer 2006, Sumaila and Walters 2007). Fig. 1 demonstrates this possibility by showing the results of a model of the Atlantic cod stock off Newfoundland for discount rates ranging from 0 to 25\% (Ainsworth and Sumaila 2005). We see from this figure that under sole ownership of the cod stocks, the end-state biomass of cod keeps dropping as the discount rate increases. A discount rate of $20 \%$, which may approximate the private discount rates of cod fishers at the time, was enough to trace the recent collapse of this cod stock (Fig. 2). Therefore, a key requirement of fisheries management, namely that of ensuring the sustainable use of fishery resources through time, can be violated even if ITQs confer full property rights onto their owners.

Concentration of quotas in a particular type of vessel can occur as a consequence of the implementation of ITQs. This situation could lead first to biological losses and then to economic losses if these vessels target only a certain age group of fish; for example, older fish (Armstrong and Sumaila 2001). If the government and taxpayers are also led to believe that ITQ owners are wealthy enough to pay for resource management, then contrary to what the economic theory of ITQs predicts, the industry may end up paying for only industry-related functions and ignoring conservation-related management functions (Edwards 1994). Furthermore, ITQs are not likely to deliver on their promise of good stewardship if those who own the fishing quotas are different from those who actually fish. In this situation, the incentives for good management felt by the owners of the ITQs are not necessarily shared by the fishers, as the latter will not see the full returns from good stewardship.

Uncertainty (for example, stock assessment information) may prevent ITQs from solving the efficiency problem (for example, Walters and Pearse 1996, Asche et al. 1997). It is worth noting that some of the efficiency gains from the implementation of ITQs derive from elongation of the fishing season. Often forgotten, however, is that this gain can be at the expense of the processing sector of the fishery chain (Matulich et al. 1996, Bromley 2009). To determine the real economic efficiency gains from ITQs, it is important to avoid double counting and include all the costs and benefits throughout the fishery industry. Some of the positive effects of ITQs with respect to stock assessment are that ITQs encourage better monitoring and enforcement as well as more precise setting of TACs (Munro et al. 2009).

ITQs are based on catch quotas, which in turn rely on robust estimates of the resource stock abundance. However, these estimates are subject to uncertainty and oftentimes to politically motivated interference. If such factors are not properly addressed, any resulting overestimates of abundance can lead to stock collapse irrespective of the quality of the ITQ scheme in place (Walters and Pearse 1996). The reliability of stock abundance data in ITQ schemes also decreases whenever ITQs encourage quota busting, which is the practice of quota holders 
Fig. 1. End-state cod biomass (year 2000) resulting from optimal catch strategies, maximizing the net present value at various discount rates. Modeling was performed using the Ecopath software suite (www. ecopath.org). A Monte Carlo procedure was used to vary basic Ecopath parameters (biomass,

production, and consumption) for all species groups $(n=20, \mathrm{CV}=0.2)$. Error bars indicate \pm 1 standard deviation around the mean. The broken line shows the real-world cod biomass in 2000, as estimated by virtual population analysis. This ecosystem model was adapted from Ainsworth and Sumaila (2005).

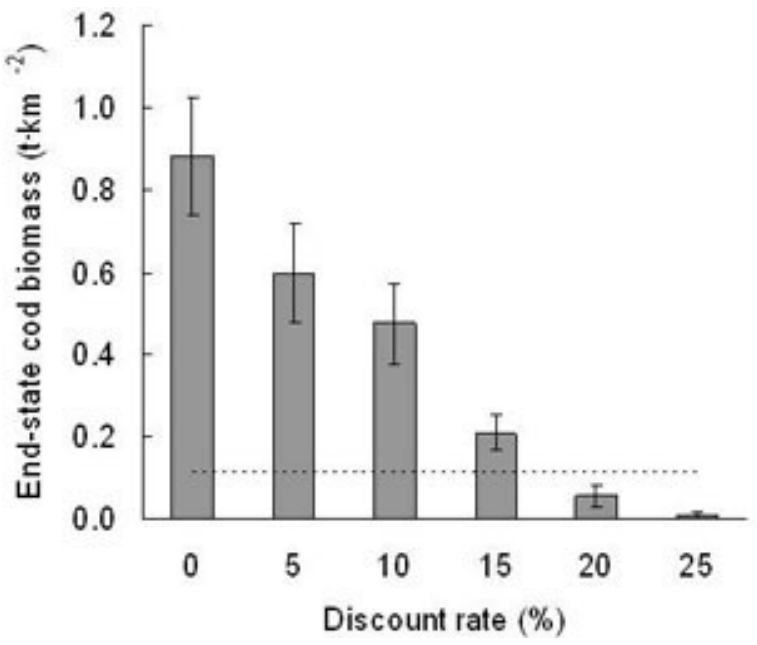

catching more than their allocation (Squires et al. 1998). The possibility of further errors in stock assessment is magnified by the significant incidence of illegal, unreported and unregulated (IUU) fishing worldwide (Sumaila et al. 2006, High Seas Task Force 2006).

An additional problem for ITQs is the practice of high grading and discarding, in which the less valuable species of fish (alive or dead) are thrown back into the sea. The goal of such ITQ owners is to make sure that their quotas are filled with the most valuable fish available. This behavior is clearly detrimental to conservation (Alverson et al. 1994). The incentives for high grading and discarding are reported to be large under ITQ schemes (Vestergaard 1996). Thus, the extra cost of monitoring and enforcement that will likely be needed to curb this tendency may undermine the efficiency benefits that ITQs are supposed to create. There are also doubts about the usefulness of ITQ schemes for managing the species-rich and datapoor artisanal fisheries that are typical of (but not exclusive to) tropical waters (Pauly 1996). This is partly because these highly multispecies fisheries have a significant bycatch of non-targeted species (Baulch and Pascoe 1992).

All of these difficulties imply that ITQs, in and of themselves, will not be able to halt the broader negative impacts of fishing on the ecosystem. In fact, Essington (2010) confirmed this implication in a study of 15 catch shares programs in North America. The author came to the conclusion that catch shares do not improve the health of fisheries. Similarly, Gibbs (2009) argued that "the individual and especially transferability component of an ITQ right ... a actually [has] very important ramifications for non-target species and benthic habitats".

\section{SOCIAL AND EQUITY CONCERNS WITH ITQ MANAGEMENT}

Social scientists other than economists argue that whatever the potential economic benefits of ITQs, they act contrary to principles of equity and social justice in fishing communities wherever they have been tried, and therefore are not appropriate for managing certain fisheries (Davis 1996, McCay et 
Fig. 2. Atlantic cod biomass profile calculated from a virtual population analysis (solid line) and optimal biomass profiles calculated by maximizing net present values at discount rates of $0 \%$ (solid circles) and 20\% (open circles). Modeling was performed using the Ecopath software suite (www.ecopath.org). A Monte Carlo procedure was used to vary basic Ecopath parameters (biomass, production and consumption) for all species groups $(n=20, \mathrm{CV}=0.2)$. Error bars indicate \pm 1 standard deviation around the mean. This ecosystem model was adapted from Ainsworth and Sumaila (2005).

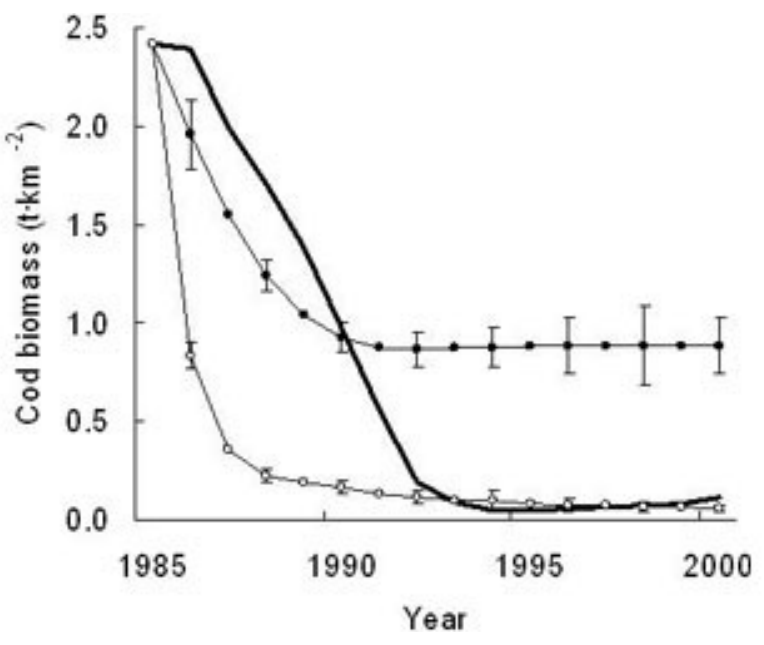

al. 1998). An important issue in this connection relates to the initial allocation of ITQs to fishers (Matulich and Sever 1999, Macinko and Bromley 2002, Bromley 2009). Concentration of fishing power has been noted in many fisheries in which ITQ schemes have been introduced (Grafton 1996, Eythorsson 1996). In economic terms, this is not considered a problem because the proponents of ITQs expect such concentration to take place. In fact, this is one of the channels through which the introduction of ITQs is expected to achieve economic efficiency (Hannesson 1996). It is argued that the more efficient fishers will buy out their less efficient counterparts, and in so doing increase the returns to the fishery overall. This phenomenon can be beneficial in that the job structure may change from fewer part-time jobs to more full-time jobs, even though the total number of full-time equivalent jobs may decrease.

Nevertheless, the concentration of ITQs in the hands of a few large fishing companies has attracted a lot of debate, even among economists. Some of the main concerns include fears of (i) a monopoly power developing in a fishery; (ii) increased social inequity; and (iii) big players becoming bigger mainly because they have more effective lobbying machinery, rather than because they are more economically efficient than small-scale operators (Sumaila and Watson 2002). In an analysis of B.C. halibut fishery ITQs, Pinkerton and Edwards (2009) came to the conclusion that issues of ITQ concentration are very important and cannot be ignored.

\section{A BALANCED APPROACH TO THE USE OF ITQS AND CATCH SHARES IN FISHERIES MANAGEMENT}

From the foregoing, it is clear that ITQs have their merits. Because they are underpinned by TACs, ITQs can constrain the catch and therefore become valuable fisheries management tools. On the other hand, ITQs also have their disadvantages, and it is increasingly acknowledged that they cannot be seen as a panacea for solving fisheries management problems (Hilborn et al. 2005, Townsend et al. 2006, Pinkerton and Edwards 2009, Gibbs 2009, Essington 2010, Clark et al. 2010). ITQs do not confer full property rights to their owners, and we have seen that even if ITQs were to provide such 
rights, there would still be conservation and social concerns. Hence, ITQ management, where implemented, needs to be part of a broad management system that can address the shortcomings of ITQs. Measures are needed to ensure that ITQs work not only to improve economic efficiency but also to safeguard the sustainable and equitable use of the fishery resources and the ecosystems that support them.

Below are some of the strategies that need to be part of an ITQ management system if it is to achieve economically, ecologically, and socially desirable outcomes:

- ITQs must be supported by an arms-length stock assessment unit and backed by strong arms-length monitoring, control, and surveillance (MCS) to deal with the lack of full property rights and to prevent the possible "emptying" of the ocean of fish under certain conditions. Arms-length monitoring is crucial, because it has been argued that well-functioning ITQ schemes encourage fishers to collect and disseminate enough relevant biological and catch quota data. While such actions by fishers are laudable, it is important for ensuring sustainability that stock assessments (validated with local ecological knowledge) and MCS are maintained independently.

- To mitigate against the dilution of ITQ performance that can occur when quota owners are not fishers, ownership of ITQs may need to become more restricted to the people who actually fish the stocks.

- Resource sustainability must be ensured by taking an ecosystem-based management approach, which includes paying special attention to the management of essential habitat, the use of safe minimum biomass levels, the application of input controls, and so on. Networks of reasonably large protected marine areas should also be established during the implementation of ITQs to deal broadly with the ecosystem effects of overfishing, to allow for recovery, and to allow for the effects of uncertainty in the performance of ITQs. Such networks should be designed to be compatible with conservation goals and ITQ objectives.
- Ecological and/or environmental quotas need to be in place to make ITQ schemes capable of functioning properly in the context of ecosystem-based management of fisheries. In other words, quotas need to be allocated to the ecosystem before catch quotas are set. This idea is another way of expressing a safe minimum biomass level as an ecosystem management goal: fisheries management needs to stipulate the level of biomass of each species it wants to maintain in the ecosystem so that all these species can continue to function and evolve. All other allocations of biomass to the various sectors of a fishery (as catch) should be made only after the mandated ecosystem goal has been attained.

- Limits should be imposed to the quota that can be held by each quota owner to mitigate the social problem of concentration of fishing power. It is worth noting that this is already a feature of many existing ITQ systems. In some fisheries, equity concerns may be alleviated by allocating ITQs to "communities" in the form of community transferable quotas (CTQs) or to residents of a territorial area as territorial user rights in fisheries (TURFs) quota systems (Wingard 2000, Christy 1982). With such schemes in place, the economic efficiency benefits of ITQs may be captured while minimizing their negative social impacts.

- Auctioning of quotas could be used in some fisheries (Macinko and Bromley 2002, Bromley 2009) to deal with the problem of the initial allocation of quotas and its equity implications. In the Falkland Islands, for example, most fish resources are auctioned on an annual basis (Barton 2002). Similarly, the rights to fish geoducks in specified tracts within Washington State are sold at annual auctions (Orensanz et al. 2005). It is important to note that auctions will not work everywhere because of social concerns and because fishers may not have significant equity to buy into the fishery in an auction. These concerns could be mitigated through the allocation of community quotas and the establishment of license banks and funding mechanisms for community fishing associations. 


\section{CONCLUSION}

ITQs are clearly not a panacea for ensuring the sustainable management of fishery ecosystems. It appears that there is no silver bullet for the problems in fisheries management, so the struggle to govern the commons continues unabated (Dietz et al. 2003). ITQs can only be expected to be part of the toolkit available to fisheries managers. When ITQs are contemplated for use in the management of fisheries, they need to be carefully designed as part of a broad ecosystem-based management scheme to meet the three generally accepted objectives of modern fisheries management: ecological, economic, and social sustainability.

Responses to this article can be read online at: http://www.ecologyandsociety.org/vol15/iss3/art36/ responses/

\section{Acknowledgments:}

Discussions with Colin Clark, Gordon Munro, Megan Bailey, Bruce Turris, Evelyn Pinkerton, Ivar Ekeland, Daniel Bromley, and many others have helped me in formulating the arguments in this paper. Also, participants in the session entitled "The Privilege to Fish" at the 2008 Annual Meeting of the American Association for the Advancement of Science provided useful insights. I thank the editor and two anonymous referees for helpful comments. The Gordon and Betty Moore Foundation, the Pew Charitable Trusts, the Sea Around Us Project (UBC Fisheries Centre), and the Global Ocean Economics Project (UBC Fisheries Centre) supported the work.

\section{LITERATURE CITED}

Ainsworth, C., and U. R. Sumaila. 2005. Intergenerational valuation of fisheries resources can justify long-term conservation: a case study in Atlantic cod (Gadus morhua). Canadian Journal of Fisheries and Aquatic Sciences 62:1104-1110.

Alverson, D. L., M. H. Freeberg, S. A. Murawski, and J. G. Pope. 1994. A global assessment of bycatch and discards. Food and Agricultural Organization (FAO) Technical Paper No. 339, FAO, Rome, Italy.
Armstrong, C. W., and U. R. Sumaila. 2001. Optimal allocation of TAC and the implications of implementing an ITQ management system for the North-East Arctic cod. Land Economics 77:350-359.

Arnason, R. 1997. Property rights as an organizational framework in fisheries. Pages 99-144 in B. L. Crowley, editor. Taking ownership: property rights and fishery management on the Atlantic Coast. Atlantic Institute for Market Studies, Halifax, Nova Scotia, Canada.

Asche, F., K. G. Salvanes, and F. Steen. 1997. Center for fisheries economics report. Foundation for Research in Economics and Business Administration, Bergen, Norway.

Barton, J. 2002. Fisheries and fisheries management in Falkland Islands conservation zones. Aquatic Conservation 12:127-135.

Baulch, K. and S. Pascoe. 1992. Options for bycatch management in the south east fishery. Australian Fisheries 51:10-11.

Bromley, D. 2009. Abdicating responsibility: the deceits of fisheries policy. Fisheries 34(6):280-302.

Christy, F. T., Jr. 1982. Territorial use rights in marine fisheries: definitions and conditions. Food and Agricultural Organization (FAO) Technical Paper No. 277. FAO, Rome, Italy.

Clark, C. W. 1973. The economics of overexploitation. Science 181:630-634.

Clark, C. W., G. Munro, and U. R. Sumaila. 2010. Limits to the privatization of fishery resources. Land Economics 86(2):209-218.

Copes, P. 1986. A critical review of the individual quota as a device in fisheries management. Land Economics 62:278-291.

Costello, C., S. Gaines, and J. Lynham. 2008. Can catch shares prevent fisheries collapse? Science 321:1678-1681.

Davis, A. 1996. Barbed wire and bandwagons: a comment on ITQ fisheries management. Review of Fish Biology and Fisheries 6:97-107.

Dewees, C. M. 1998. Effects of individual quota systems on New Zealand and British Columbia 
fisheries. Ecological Applications, Supplement: Ecosystem Management for Sustainable Marine Fisheries 8:S133-S138.

Dietz, T., E. Ostrom, and P. C. Stern. 2003. The struggle to govern the commons. Science 302:1907-1912.

Edwards, S. F. 1994. Ownership of renewable ocean resources. Marine Resource Economics 9:253-273.

Essington, T. 2010. Ecological indicators display reduced variation in North American catch share fisheries. Proceedings of the National Academy of Sciences 107(2):754-759. [Online] URL: www.pna s.org/cgi/doi/10.1073/pnas.0907252107.

Eythorsson, N. 1996. Theory and practice of ITQs in Iceland: privatization of common fishing rights. Marine Policy 30:269-281.

Gibbs, M. T. 2009. Individual transferable quotas and the ecosystem-based fisheries management: it's all in the T. Fish and Fisheries 10:470-474.

Grafton, R. Q. 1996. Individual transferable quotas: theory and practice. Reviews in Fish Biology and Fisheries 6:5-20.

Grafton, R. Q., T. Kompas, and R. W. Hilborn. 2007. Economics of overexploitation revisited. Science 318(5856): 1601 .

Hannesson, R. 1996. On ITQs: an essay for the special issue of Reviews in Fish Biology and Fisheries. Reviews in Fish Biology and Fisheries 6:91-96.

High Seas Task Force. 2006. Closing the net: stopping illegal fishing on the high seas. Governments of Australia, Canada, Chile, Namibia, New Zealand, and the United Kingdom; World Wildlife Fund; International Union for Conservation of Nature; and the Earth Institute at Columbia University.

Hilborn, R., J. M. Orensanz, and A. M. Parma. 2005. Institutions, incentives and the future of fisheries. Philosophical Transactions of the Royal Society B: Biological Sciences 360:47-57.
Macinko, S., and D. W. Bromely. 2002. Who owns America's fisheries? Island Press, Washington, D. C., USA.

Matulich, S. C., R. C. Mettelhammer, and C. Reberte. 1996. Toward a more complete model of individual transferable fishing quotas: implications of incorporating the processing sector. Journal of Environmental Economics and Management 31:112-128.

Matulich, S. C., and M. Sever. 1999. Reconsidering the initial allocation of ITQs: the search for a Pareto-safe allocation between fishing and processing sectors. Land Economics 75:203-219.

McCay, B. J., R. Apostle, and C. F. Creed. 1998. Individual transferable quotas, comanagement and community: lessons from Nova Scotia. Fisheries 23:20-24.

Moloney, D., and P. Pearse. 1979. Quantitative rights as an instrument for regulating commercial fisheries. Journal of the Fisheries Research Board of Canada 36:859-866.

Munro, G. R., B. Turris, C. Clark, U. R. Sumaila, and M. Bailey. 2009. Impacts of harvesting rights in Canadian Pacific fisheries. Statistical and Economic Analysis Series, Economic Analysis No. 1-3, Economic Analysis and Statistics Branch, Ottawa, Ontario, Canada.

Munro, G., and T. Pitcher. 1996. Editorial Comment. Reviews in Fish Biology and Fisheries 6:1-3.

Orensanz, J. M., A. M. Parma, G. Jerez, N. Barahona, M. Montecinos, and I. Elias. 2005. What are the key elements for the sustainability of "S-fisheries"? Insights from South America. Bulletin of Marine Science 76:527-556.

Pauly, D. 1996. ITQ: the assumptions behind a meme. Reviews in Fish Biology and Fisheries 6:109-112.

Prager, M. H., and K. W. Shertzer. 2006. Remembering the future: a commentary on "Intergenerational discounting: a new intuitive approach". Ecological Economics 60:24-28. 
Pinkerton, E., and D. N. Edwards. 2009. The elephant in the room: the hidden costs of leasing individual transferable fishing quotas. Marine Policy 33:707-713.

Squires, D., H. Campbell, S. Cunningham, C. Dewees, R. Q. Grafton, S. F. Herrick, Jr., J. Kirkley, S. Pascoe, K. Salvanes, B. Shallard, B. Turris, and N. Vestergaard. 1998. Individual transferable quotas in multispecies fisheries. Marine Policy 22:135-159.

Sumaila, U. R., J. Alder, and H. Keith. 2006. Global scope and economics of illegal fishing. Marine Policy 30(6):696-703.

Sumaila, U. R., and M. Bawumia. 2000. Ecosystem justice and the marketplace. Pages 140-153 in H. Coward, R. Ommer, and T. J. Pitcher, editors. Just fish. Institute of Social and Economic Research (ISER), Memorial University, St. John's, Newfoundland, Canada.

Sumaila, U. R., L. Teh, R. Watson, P. Tyedmers, and D. Pauly. 2008. Fuel price increase, subsidies, overcapacity, and resource sustainability. ICES Journal of Marine Science 65(6):832-840.

Sumaila, U. R. and C. Walters. 2005. Intergenerational discounting: a new intuitive approach. Ecological Economics 52:135-142.

Sumaila, U. R. and C. Walters. 2007. Making future generations count: comment on "Remembering the future". Ecological Economics 60:487-488.

Sumaila, U. R., and R. Watson. 2002. The rights to fish - an ecological critique of individual transferable quotas. Pages 41-43 in T. Ward, D. Tarte, E. Hegerl, and K. Short, editors. Policy proposals and operational guidance for ecosystembased management of marine capture fisheries. World Wildlife Fund for Nature Australia, Australia.

Townsend, R. E., J. McColl, and M. D. Young. 2006. Design principles for individual transferable quotas. Marine Policy 30:131-141.

Vestergaard, N. 1996. Discard behavior, high grading and regulation: the case of Greenland shrimp fishery. Marine Resource Economics 11:247-266.
Walters, C., and P. Pearse. 1996. Stock information requirements for quota management systems in commercial fisheries. Reviews in Fish Biology and Fisheries 6:21-42.

Wingard, J. D. 2000. Community transferable quotas: internalizing externalities and minimizing social impacts of fisheries management. Human Organization 59:48-57.

World Bank. 2009. The sunken billions: the economic justification for fisheries reform. World Bank, Washington, D.C., USA. 